\title{
ATTENDANCE RECOGNATION BY USING SMART METER BASED ON IOT STUDY CASE: FST UIN JAKARTA
}

\author{
Feri Fahrianto ${ }^{1}$, Hendra Bayu Suseno ${ }^{2}$, Alfatta Reza ${ }^{3}$ \\ Fakultas Sains dan Teknologi Universitas Islam Negeri Syarif Hidayatullah Jakarta \\ Email: feri.fahrianto@uinjkt.ac.id_hendra.bayu@uinjkt.ac.id_arwinnersyah@gmail.com
}

\begin{abstract}
ABSTRAK
Universitas Islam Negeri Syarif Hidayatullah Jakarta adalah universitas riset kelas dunia Islam yang bertempat di tepi kota Jakarta; telah mencatat semua proses bisnisnya menggunakan sistem informasi yang disediakan oleh Pustipanda (Pusat Teknologi Informasi dan Basis Data). Academic Information System (AIS) telah digunakan untuk merekam kegiatan akademik di Universitas selama hampir satu dekade, sistem informasi ini memiliki fungsi secara manual untuk memonitor kehadiran dosen. Dalam penelitian ini, sistem otomatis untuk mendeteksi kehadiran dosen dibangun dan mensinkronisasi ke sistem informasi akademik Universitas. Internet of Things merupakan objek yang mengirimkan data antar perangkat dengan menggunakan koneksi internet. Dengan menggunakan teknologi ini, perangkat kecil mampu mengimplementasikan sistem elektrik untuk mendeteksi aktivitas yang terjadi di dalam ruangan. Hal yang diimplementasikan dalam ruangan dapat memonitor perangkat elektronik mana yang aktif dan gerak objek bergerak, juga posisi objek. Koneksi komunikasi antara smart phone dan access point ke ruang kelas juga dapat dipantau untuk mengidentifikasi identitas dosen.
\end{abstract}

Kata Kunci: Internet of Thing, Kehadiran, Smart Meter

\begin{abstract}
State Islamic University Syarif Hidayatullah Jakarta, Islamic world-class research university placed in the edge of Jakarta; record all its business process using Information System Provided by Pustipanda (The Center of Information Technology and Database). The Academic Information System (AIS) has been used for recording an academic activity in university for almost a decade, this information system has manually functionality for monitoring the lecturer attendance. In this research, the automatic system to detect attendance from lecturer was built and synchronize to university academic information system. Internet of Things, objects that transmit data among devices by using Internet connection. By using this technology, a small device is able to implement into electrical system to detect an activity occured in the room. Things implemented in the room are able to monitor which electronic device is active and motion of moving objects, also the position of objects. The communication connection between smart phones and acces point in the class room is also monitored in order to identify the lecturer identity.
\end{abstract}

Keyword: Internet of Thing, Attendance, Smart Meter 


\section{BACKGROUND}

Smart meter by definition is an electronic device that records consumption of energy in intervals of an hour or less and communicates that information at least daily back to the utility for monitoring and billing. The monitoring in smart meter ussually used for billing purpose only but here, the researchers intent to have other function, monitoring can be used for detecting someone activity and attendance. The current that is monitored from electronic device has hidden meaning that human activity is occuring in the rooms.

State Islamic University Syarif Hidayatullah Jakarta monitors the lecturer attendance by manual manner using insformation system application. The acadmic information system (AIS) has been used for recording an academic activity in university for almost a decade, this information system has a functionality for detecting the lecturer attandancity, but the attendance system needs to be improved by transforming the process from manual to automatic process. In this research, the system to detect attendance from lecturer is build by mounting IoT devices in each class room.

Internet of Things, based on ITU-T 2015, some devices are able to transmit aggregate data among object by low energy internet protocol. It means by this technology the Internet used has been widely changed, from human-to-machine communication to machine-to-machine communications. By using this technology, Internet of things can be implemented into electrical system to monitorize an activity occured in the classroom. Things implemented in the room are able to monitor electronic device, motion of moving objects, and also the position of objects. The communication between smart phones and acces point in the class room is also monitored in order to identify the lecturer identity.

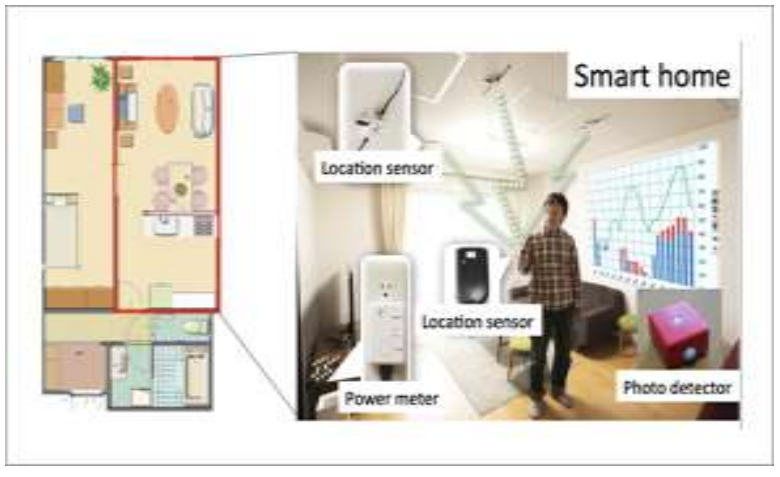

Figure 1. Smart monitoring system

All the objects are built using microcontroller follow a very simple pattern that knows the Interactive Device. The device processes the information getting from the sensors with all its behaviour implemented as a software. The device will be able to interact afterward with the world using actuators, electronic components that can convert an electric signal into a physical action [8].

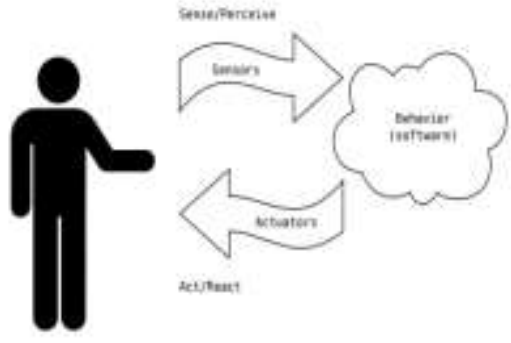

Fig 1. Interactive device

Sensors and actuators are electronic components that allow a piece of electronics to interact with the world. As the microcontroller is a very simple computer, it can process only electric signals. Once the sensors have been read, the device has the information needed to decide how to react. The decision-making process is handled by the microcontroller, and the reaction is performed by actuators [8].

\section{RESEARCH METHODOLOGY} as follow:

Methods are used in this research are

\subsection{Literature Reviews}

At this step, collecting all books and articles that are relevant to this research is conducted. Several textbooks are used in this research in example books that contain theory about UML, Embedded System, Electronics Circuits, and Database System. An article that 
has similarity with this research also is collected.

\subsection{Observation and Interview}

Observation is done to research object Faculty of Science and Technology State Islamic Syarif Hidyatullah University of Jakarta (FST) from May 2017-October 2017.

\section{ANALYSIS AND DESIGN}

In this chapter, the design process and analysis of the system will be discussed. The system build by using a framework called SCRUM. Every step of SCRUM methodology is conducted and implemented. The SCRUM methodology has several steps and iteration. The first step in this methodology is collecting all data and facts about Pustipanda condition, and then analyze the facts, observe the environtment, problem identification, design and programming, testing the system, and deployment in site.

\subsection{Collecting All Data}

The researcher tries to collect all data and facts about attendance system in Faculy Science and Technology, starting with reading the schedule database. Several incidents are found in the system. Some lectures are running the class outside the schedule provided by a system. This situation showed that the lecturer does the teaching illegaly

\subsection{Fact Analysis.}

\subsubsection{Scope}

The first thing should be done in determining the all elements needed by the system are defining the scope. The scope that the researcher does in this research is in the Faculty of Science and Technology.

The researcher monitored all the teaching activity from all classrooms in the faculty. This captured data is used to build database systems that are used by designed attendance system. The attandance system should be real-time and stored to the server. And then the system is able to show and visualize locally.

\subsubsection{The Hardware Requirement Analysis}

Designing a prototype attendance monitoring system, researcher used several hardware and software for building a complete system. The Hardware uses microcontroller components such as sensors for read in current and detecting MAC address. The specification for each component is also important to make sure the system working perfectly. Following is list of components used in this power monitoring system:

\section{Table 1 Hardware analysis}

\begin{tabular}{|l|l|l|l|}
\hline No. & Components & Qty & Function \\
\hline 1. & Raspberry Pi 3 & 8 & $\begin{array}{l}\text { As center of computation } \\
\text { and processing in the } \\
\text { system. }\end{array}$ \\
\hline 2. & $\begin{array}{l}\text { Node MCU ESP } \\
8266\end{array}$ & 8 & $\begin{array}{l}\text { Acting as client agent to } \\
\text { detect current and pass to } \\
\text { raspberry pi }\end{array}$ \\
\hline 3. & SCT 013 100A & 8 & Current Sensor \\
\hline 4. & $\begin{array}{l}\text { Power Source USB } \\
5 \text { V 2.0 A }\end{array}$ & 8 & $\begin{array}{l}\text { Giving Power for } \\
\text { Raspbery Pi }\end{array}$ \\
\hline 5. & Power Bank & 16 & $\begin{array}{l}\text { Giving Power for } \\
\text { Raspberry Pi and ESP } \\
\text { 8266 }\end{array}$ \\
\hline
\end{tabular}

\subsubsection{Software and Tools Analysis}

Software implemented in this power monitoring system is build and developed in order to make the hardware working perfectly as they planned. Following is the list of the software used by the system.

Tabel 2. Software analysis

\begin{tabular}{|l|l|l|}
\hline No & Components & Function \\
\hline Arduiso IDE & $\begin{array}{l}\text { As connection between } \\
\text { hardware and software and } \\
\text { giving instruction to Node } \\
\text { MCU. }\end{array}$ \\
\hline 2 & Linux Embedded & $\begin{array}{l}\text { Real time Operating System } \\
\text { Software ases for operate the } \\
\text { raspberry pi }\end{array}$ \\
\hline 3 & PHP, HTML, and CSS & $\begin{array}{l}\text { For Front end application in } \\
\text { the server }\end{array}$ \\
\hline 4 & Python & Uses as interface in RTOS \\
\hline
\end{tabular}

\subsection{Current System Analysis}

The attendance system that uses in Faculty is using Academic Information System and manually self signing autograph. This system only required the lecturers to sign the attendance system before they came to the class. 
Sometimes the lecturers do the teaching in other room or not suited to his/her schedule provided by academic information system. By this condition the researcher design a attendance monitoring system based on IoT. This system able to capture electric current, temperature, and humidity and stored in database, and show the graphic as visualisation for further analysis.

\subsubsection{Requirement Analysis}

This phase objective is to determine what the system should do for fullfilling system objectives. This matter is determined in order to make attendance system that could help Faculty to monitor and to analyze every teaching activity in Faculty.

Requirement will be divided into two section, the first section is the functional requirements, the definition of functional requirements is activity and services that the system should provide in order to make the system working. The second section is Non-functional requirements, by the definition the nonfunctional requirements is featerus that the system has in order to make the system more easy to used, more advanced to operate.

\subsubsection{Functional Requirements}

The system build should have fucntional requirements as follow:

1. Able to monitor and capture activity inside the classroom.

2. Stored the data into database.

3. Visual the data into graph and digital meter

\subsubsection{Nonfunctional Requirements}

Nonfunctional Requirementsfrom the system build as follow as shown in Table 3

Table 3. Nonfunctional requirement

\begin{tabular}{|c|l|}
\hline Jenis kebutuhan & Penjelasan \\
\hline 1. Graphical User Interface & $\begin{array}{l}\text { a. Graphical user interface using } \\
\text { graphic and digital meter. }\end{array}$ \\
2. Database & $\begin{array}{l}\text { b. Giving relational and high } \\
\text { capacity of data }\end{array}$ \\
3. Historical Data & $\begin{array}{l}\text { c. Able to giving a historical } \\
\text { data }\end{array}$ \\
\hline
\end{tabular}

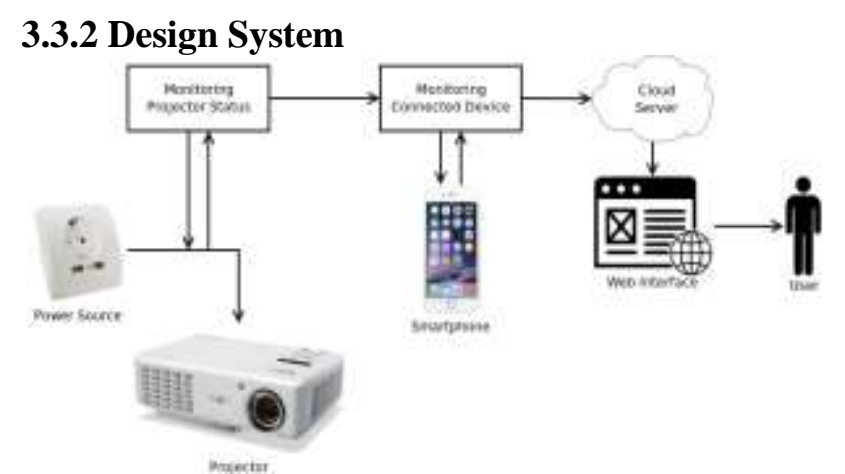

Figure 2. Design system

At Figure 2 explained about the attendance system based on IoT. Those monitoring system monitor the power projector by using SCT 013 and also the deviation of chamber temperature following is the explaination from the system:

1. Raspbery Pi3 use as central processing unit and access point.

2. SCT 013 sensor, current from power source to projector is measured and digitalize by using NodeMCU.

3. NodeMCU with defined treshold check if projector on or off and send data to Raspberry Pi3.

4. Raspberry pi scan mac address from connected device and join it with projector status data and send the data into cloud server.

5. Cloud server send the data to web server and visualize the data.

6. User able to monitor the attendance of lecturers.

7. User able to monitor the power and the temperature.

From data forwarded to database server and database server will push to web server. By using webbrowser the data are viewed to user in realtime.

\subsection{Workshop Design}

Design or designing a system could be define as task that focus on detail specsification of solution based on computer. If system analysis focus on business process otherwise this would focus on technical implementation from a system.

Designing based on object ot object oriented design, one of the example of model driven approach. This approach take visualization of system model for documenting all the technical aspect from impelementation of a system. At this time this approach has 
been escalated by the tools that work automaticaly called CASE Tools. This tools help to check consistancy especially ruled based error checking.

\subsubsection{Application Design}

\subsubsection{Identification of User}

Actor Identification or user identification will be taken from the functionality of the system. This fucntionality from the system provided by use case diagram. Use case diagram will tell the final result to the actor. Based on those specification, the actor could be determined on a system.

Based on the explanation from the previous chapter use case diagram consist of workflow in a system. The actors is something that act outside the system. For detail explanation will be given in the table 4

Tabel 4. Requirement actor and use case

\begin{tabular}{|l|l|l|}
\hline Requirement & Actor & Use Case \\
\hline $\begin{array}{l}\text { 1. } \begin{array}{l}\text { Microcontroller send } \\
\text { data to server }\end{array} \\
\text { 2. User/Staff } \\
\text { monitorize the graph }\end{array}$ & User & $\begin{array}{l}\text { Send data to database } \\
\text { server } \\
\text { Monitor and has }\end{array}$ \\
& $\begin{array}{l}\text { information from the } \\
\text { graph }\end{array}$ \\
\hline
\end{tabular}

\subsubsection{Use Case Diagram}

Following is the use case diagram:

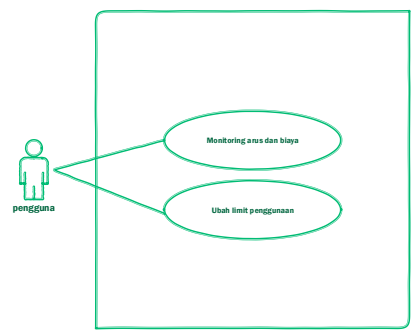

Figure 3. Use case diagram

\subsubsection{Use Case Scenario}

Use case scenario define what the system does when actor enable the use case. The Structure from use case scenario is consist of:

1. Name of Use case

2. Actor

3. Pre-Condition

4. Description with explain:

a. Main flowfrom activities that can be detailed become sub flow from activity in order to produce readable and understable documents.

b. Alternative flow to define an exception from activity

Post-condition explain state from system after the use case finish.

\subsection{Use Case Monitoring Power}

Table 5. Use case monitoring power

\begin{tabular}{|l|l|l|}
\hline Use case name & Current Monitoring \\
\hline Use case id & 1 \\
\hline Actor & User \\
\hline Description & $\begin{array}{l}\text { Use case describe an event from user/staff monitorize } \\
\text { the current value from eletric company. }\end{array}$ \\
\hline Pre-condition & Enter the system via \\
\hline Typical course & Actor action \\
\cline { 2 - 4 } of events & $\begin{array}{l}\text { 1. Open the page of } \\
\text { monitoring application fro } \\
\text { a web browser }\end{array}$ & sens visulize the data from \\
\hline Alternate & $\begin{array}{l}\text { If the system Down than the user unable to acces the } \\
\text { monitoring application }\end{array}$ \\
\hline Course & \begin{tabular}{l} 
User can be see visualzation from \\
\hline
\end{tabular} & System Response \\
\hline
\end{tabular}

\subsection{Use Case Projector Monitoring}

Table 6. Use case projector monitoring

\begin{tabular}{|l|l|l|}
\hline Use case name & Projector Monitoring \\
\hline Use case id & 2 \\
\hline Actor & User \\
\hline Description & $\begin{array}{l}\text { Use case describe an event from user/staff monitorize } \\
\text { the current value of temperature }\end{array}$ \\
\hline Pre-condition & Enter the system via \\
\hline Typical course & Actor action \\
\cline { 2 - 4 } of events & $\begin{array}{l}\text { 1. Open the page of } \\
\text { monitoring application fro } \\
\text { a web browser }\end{array}$ & 2. visualize the data from \\
\hline Portensor \\
\hline Course & $\begin{array}{l}\text { If the system Down than the user unable to acces the } \\
\text { monitoring application }\end{array}$ \\
\hline Post-condition & User can be see visualzation from \\
\hline
\end{tabular}




\subsection{Use Case Absence Monitoring}

Table 7. Use case absence monitoring

\begin{tabular}{|l|l|l|}
\hline Use case name & Absence Monitoring \\
\hline Use case id & 3 \\
\hline Actor & User \\
\hline Description & $\begin{array}{l}\text { Use case describe an event from user/staff monitorize } \\
\text { the absence of the lecture }\end{array}$ \\
\hline Pre-condition & Enter the system via \\
\hline $\begin{array}{l}\text { Typical course } \\
\text { of events }\end{array}$ & \begin{tabular}{l} 
Actor action \\
\cline { 2 - 4 } \\
1. Open the page of \\
monitoring application fro \\
a web browser
\end{tabular} & MAC addres reader \\
\hline Alternate & $\begin{array}{l}\text { If the system Down than the user unable to acces the } \\
\text { monitoring application }\end{array}$ \\
\hline Course & \begin{tabular}{l} 
User can be see visualzation from \\
\hline Post-condition
\end{tabular} & System Response \\
\hline
\end{tabular}

\subsubsection{Activity Diagram}

Activity diagram describes all activity happen in the system.

\subsection{Activity Diagram Attendance}

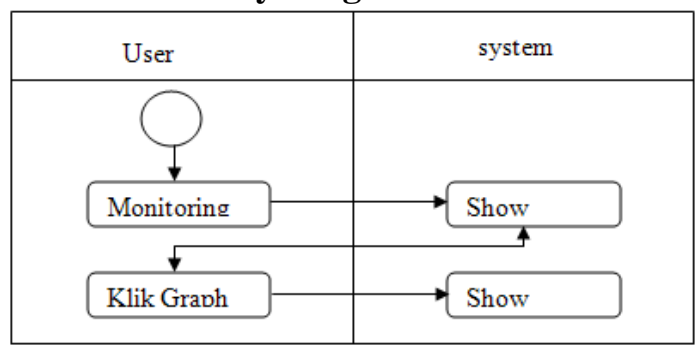

Figure 4. Activity diagram for attendance

Figure 4 explained the sequnce of activity that should be done by user in order to obtain an information of Attendance monitoring. The first steps that should be done is by using web browser to find the server address. After enter the address of web application address, the user is shown the list attendance of the lectures
3.4.1.4.2 Activity Diagram Monitoring the Projector

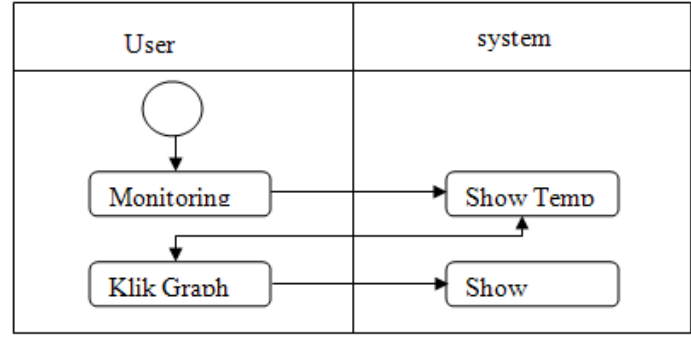

Figure 5. Activity diagram projector monitoring

Figure 5 explained the sequence of steps for monitoring the projector inside the lecture room. First of all in the web browser user type the web browser address afterward the user is able to see the graph of temperature value in the lecture room.

\subsection{Activity Diagram MAC Address Monitoring}

\begin{tabular}{|l|l|}
\hline User & system \\
\hline Monitoring & \\
\hline
\end{tabular}

Figure 6. Activity diagram MAC address monitoring

Figure 6 explained the sequence of steps for reading the MAC address. First of all in the web browser user type the web browser address afterward the user is able to see the list in the lecture room

\subsubsection{Sequence Diagram}

Sequence diagram described the behaviour of object at use case with describing the lifetime of the object lifetime.

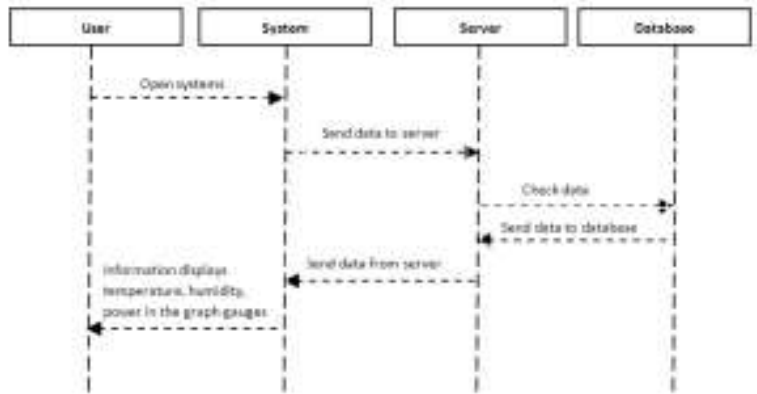

Figure 7. Sequence diagram of main page 
Figure 7 explained about the sequence of process which has been done by user to access the system. Main page of the system shows the condition of server with the measurement graph. The information given by the graph consist of the value of MAC address, projector current consumption.

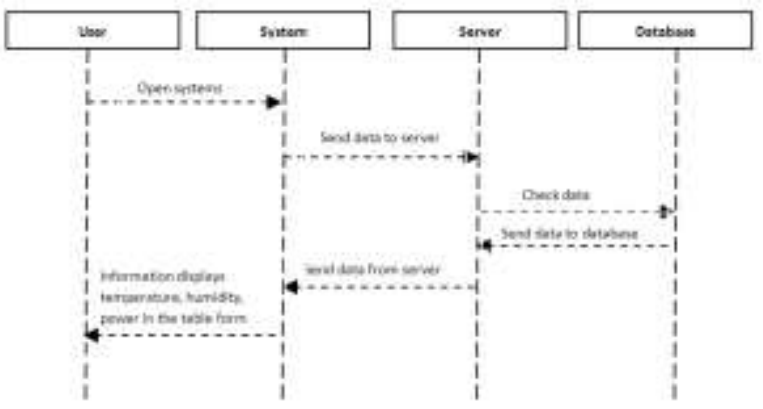

Figure 8 . Sequence diagram of monitoring

Figure 8 explained the step of activity of server which contain history of information about temperature, humidity and current. Server will take the information from database server and provided to web server.

\subsubsection{Class Diagram}

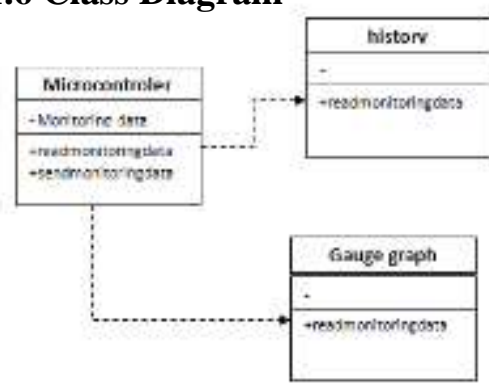

Figure 9. Application class diagram

\subsubsection{Design of Database}

The system needs database to store the information captured by sensor. The Design of database should support the information system wich based on web. Database is obtained by integrated all data which is connecting each other, mapping and entity class.

1. Table Name: lecture

Primary key: id_lecture

Foreign key: -

\begin{tabular}{|l|l|l|l|}
\hline No & Field Name & Tipe & Info \\
\hline 1 & id_lecture & Int(10) & Id lecture \\
\hline 2 & Name & Varchar(30) & Name of lecturer \\
\hline
\end{tabular}

2. Table Name: schedule Primary key:

Foreign key : id_lecture

\begin{tabular}{|l|l|l|l|}
\hline No & Field Name & Tipe & Info \\
\hline 1 & id_lecture & Int(10) & Id lecture \\
\hline 2 & Day & Varchar(30) & Name of lecturer \\
\hline 3 & Time & Varchar(30) & Time \\
\hline 4 & Courses & Varchar(30) & Courses \\
\hline 5 & Semester & Varchar(30) & Semester \\
\hline 6 & Class & Varchar(30) & Class \\
\hline 7 & Room & Varchar(30) & Room \\
\hline
\end{tabular}

3. Table Name: status

Primary key: --

Foreign key: id_lecture

\begin{tabular}{|l|l|l|l|}
\hline No & Field Name & Tipe & Info \\
\hline 1 & id_status & Int(10) & Id status \\
\hline 2 & id_lecture & Varchar(30) & Id lecture \\
\hline 3 & Infocus & Varchar(30) & Status infocus \\
\hline 4 & Mac & Varchar(30) & Status mac address \\
\hline 5 & Date & Datetime & Date time \\
\hline
\end{tabular}

\subsubsection{Interface Design}

In this step, interface is made by rules of human computer interation. By using this rule, the outlook and interface are operated easyly by user for monitoring the server with graphic visualization 


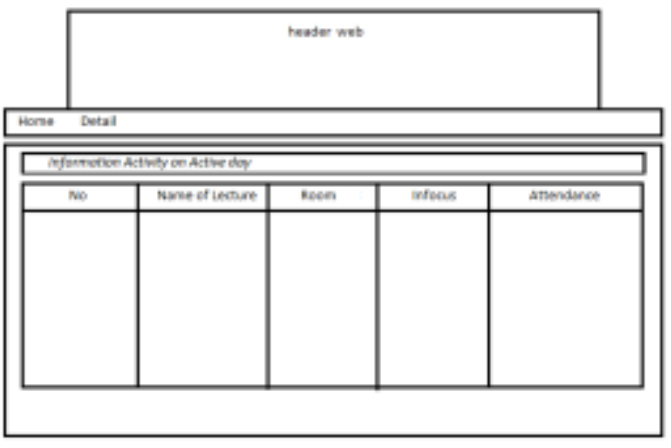

Figure 10. Application main page

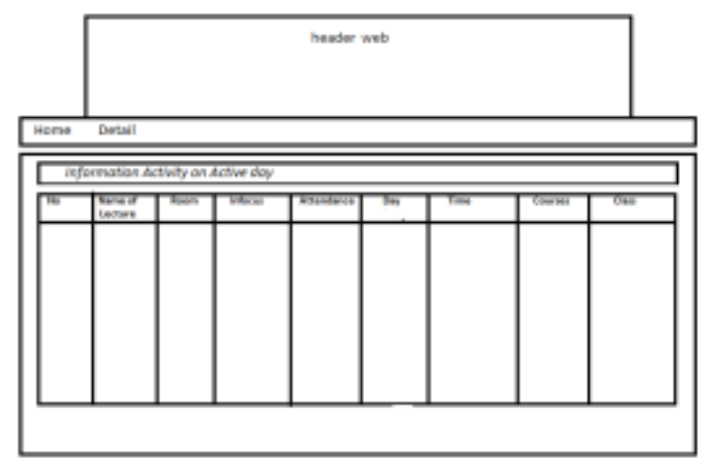

Figure 11. Detail page

\subsubsection{Coding}

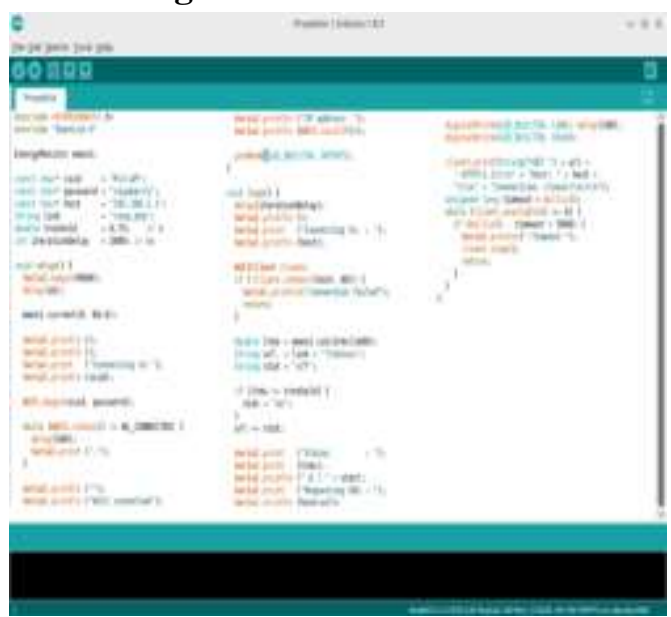

Figure 12. Code of LCD projector monitoring

In projector monitoring code there are several include code which contain module using by the code itself in order to make the system running as expected. Those include line is Emonlib.h which has functionality to convert the value of current obtained by sensor, ESP8266Wifi.h which has functionality to connect an access point.

Inside code, NodeMCU measure current from projector and check if it greater than treshold. Then code send result from measurement to raspberry pi with HTTP GET Request.

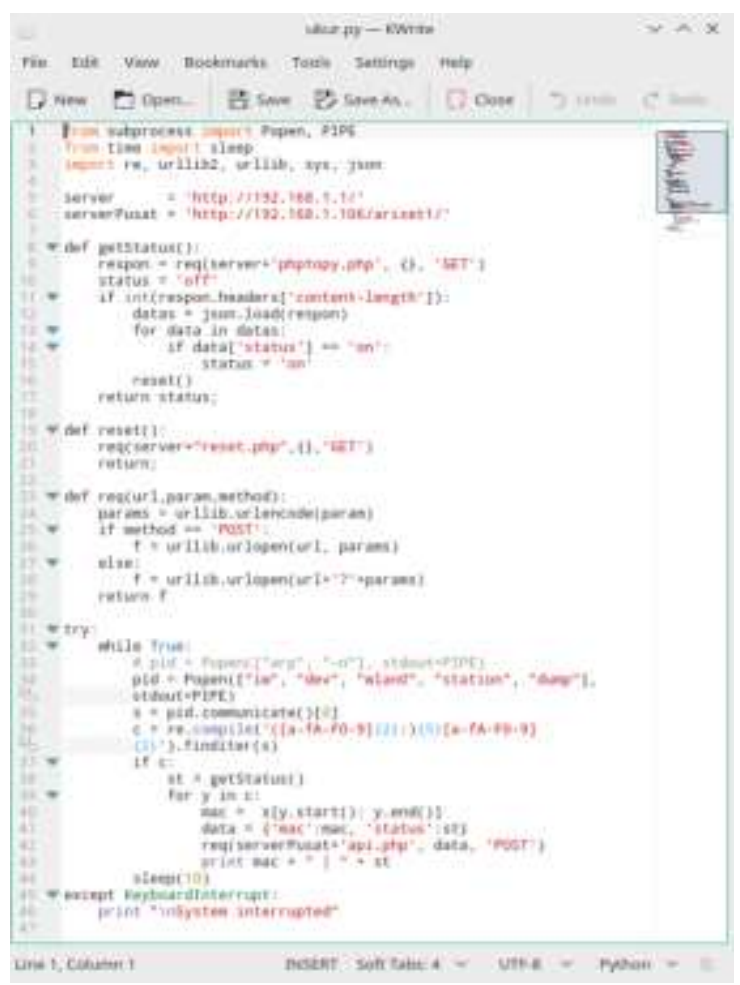

Figure 13. Code of MAC address monitoring

Inside the current monitoring code implicitly consist of two codes, one code is python code mounted in raspberry $\mathrm{Pi}$ and another one is code for arduino. Python code mounted in raspberry is used fo taking data from arduino and forward it to server. But code in arduino is used to read the value of the current sensor SCT 103.

At Arduino scketch consist of \#include line containe modules which used in order to make system working as expected. Those include line is Emonlib.h which has functionality to convert the value of current obtained by sensor.

Afterward initialization serial module is conduct in order to comunicate with raspberry pi by using serial mode. The readness of data is executed afterwards from Emonlib.h 


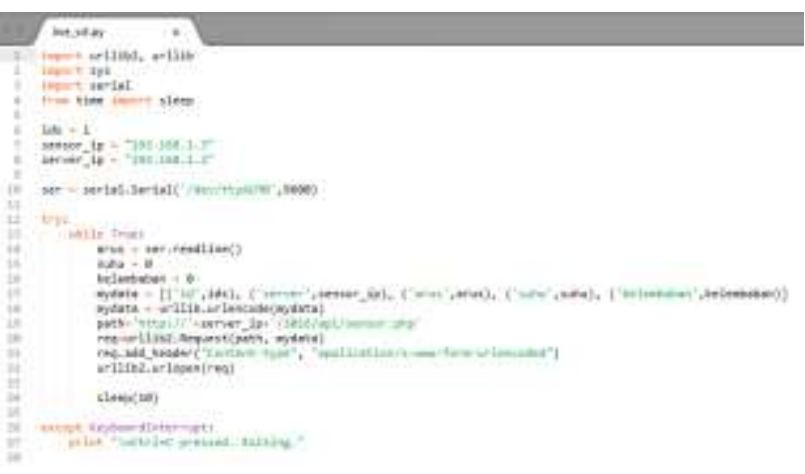

Figure 14. Python code in raspberry pi

Inside Python code in raspberry pi is conducting the serialized data readed and sent from raspberry pi. Afterward send to server by acessing php file

\subsubsection{Implementation}

The projection monitoring system used a current sensor and temperature sensor. The current sensor works with capturing the electro magnetic fields exist in the power cable. This electro magnetic field will inducted to ferrit coil inside the sensor. Afterwards the fluks magnet exist inside the sensor will be convert to current that can be measrude by coil. With little help from resistor components the sensor will give the voltage value linearly with the current measured.

The schematic diagram at current sensor, arduino and microcontroller is as follow. The microcontroller change the data from analogue to digital.

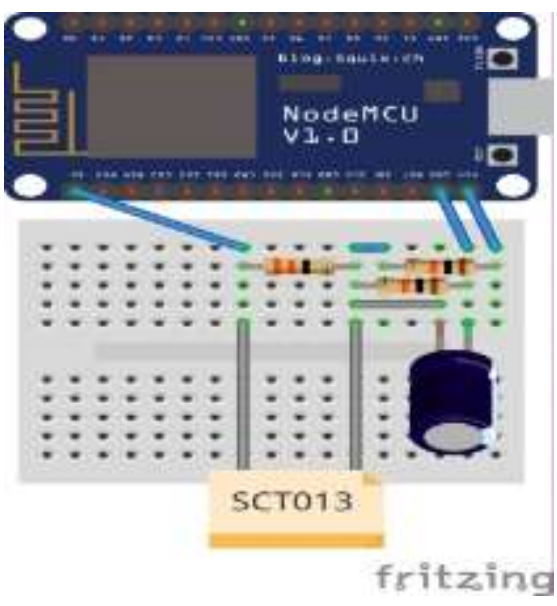

Figure 15. Schematic diagram

Alternating Current is measured by sensor with maximum range up to 30 Ampere. 30 Ampere is the RMS value from maximum value obtained by sensor. We could calculate th I max with following formula:

$\mathrm{i}(\max )=\sqrt{2} * \mathrm{i}($ ms_current $)=1.414 * 30 \mathrm{~A}=42.42 \mathrm{~A}$
Imax current sensor $=42.42 \mathrm{~A}$.
$\mathrm{i}($ sensor $)=\mathrm{i}($ measured $) / \mathrm{nb}$-turns $=42.42 \mathrm{~A} / 2000=$
$0.02121 \mathrm{~A}$
calibration_value $=(\mathrm{i}($ measured $) / \mathrm{i}($ sensor $)) / \mathrm{R}($ burden $)$
calibration_value $=(42.42 \mathrm{~A} / 0.02121 \mathrm{~A}) / 33 \Omega$
calibration_value $=2000 / 33 \Omega=60.6$

From formula we have obtained calibration value to get a normalization value is 60,6. This value used in arduino microcontroller to normalize the current value.

Data sent by arduino will be taken by raspberry pi using wireless connection. And the raspberry will be sent to database server by using wireless connection.

Following is the database design and the database will be automatically will be write by raspberry pi trough php code in order to insert the table. 


\begin{tabular}{|c|c|c|c|c|c|c|}
\hline & $T \rightarrow$ & id_status & id_lecture & infocus & mac & date \\
\hline$\square$ & $x$ & 1 & 361 & on & 40:16:7e:ee: $36: 65$ & $2017-11-1018: 22: 29$ \\
\hline 0 & $\Rightarrow x$ & 2 & 361 & off & 40:16:7e:ee:36:65 & $2017-11-10$ 18:22:48 \\
\hline$\square$ & $x$ & 3 & 362 & off & $08: 60: 6 \mathrm{e}: 94: 25: 1 \mathrm{c}$ & $2017-11-1018: 24: 39$ \\
\hline 口 & $\Rightarrow x$ & 4 & 361 & on & 40:16:7e:ee:36:65 & $2017-11-1021: 21: 09$ \\
\hline$\square$ & l $x$ & 5 & 362 & off & $08: 60: 6 \mathrm{e}: 94: 25: 1 \mathrm{c}$ & $2017-11-1021: 36: 01$ \\
\hline$\square$ & $x$ & 6 & 362 & on & $08: 60: 6 \mathrm{e}: 94: 25: 1 \mathrm{c}$ & $2017-11-1022: 17: 48$ \\
\hline$\square$ & $x$ & 7 & 345 & on & $18: 60: 6 \mathrm{e}: 94: 25: 1 \mathrm{~d}$ & 2017-11-11 21:21:49 \\
\hline D & $x$ & 8 & 345 & off & & $2017-11-1121: 22: 11$ \\
\hline$\square$ & 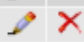 & 9 & 361 & off & $40: 16: 7 \mathrm{e}: \mathrm{ee}: 36: 65$ & $2017-11-1122: 40: 15$ \\
\hline$\square$ & l $x$ & 10 & 361 & on & $40: 16: 7 \mathrm{e}: \mathrm{ee}: 36: 65$ & 2017-11-13 10:14:01 \\
\hline$\square$ & $x$ & 11 & 361 & off & & $2017-11-13 \quad 10: 25: 48$ \\
\hline 0 & $x$ & 13 & & on & $5 c$ cf: $7 f: b 2: e 3: 35$ & $2017-11-13$ 05:08:40 \\
\hline$\square$ & $x$ & 14 & & on & c4:17:fe:88:e5:ad & $2017-11-13 \quad 05: 08: 40$ \\
\hline$\square$ & $x$ & 15 & & on & dc:85:de:a7:11:fb & $2017-11-13$ 05:08:40 \\
\hline$\square$ & $x$ & 16 & 361 & off & 40:16:7e:ee: $36: 65$ & $2017-11-13$ 05:08:46 \\
\hline 0 & $x$ & 17 & & on & 5c: cf: $7 f \cdot b 2: e 3: 35$ & $2017-11-13$ 05:08:50 \\
\hline$\square$ & $x$ & 18 & & on & c4:17:fe:88:e5:ad & $2017-11-13$ 05:08:50 \\
\hline 0 & $x$ & 19 & & on & dc:85:de:a7:11:fb & $2017-11-13$ 05:08:50 \\
\hline$\square$ & $x$ & 20 & & on & 5c:cf:7f:b2:e3:35 & $2017-11-13$ 05:09:00 \\
\hline$\square$ & $x$ & 21 & & on & c4:17:fe:88:e5:ad & $2017-11-13$ 05:09:00 \\
\hline$\square$ & $x$ & 22 & & on & dc:85:de:a7:11:fb & $2017-11-13$ 05:09:00 \\
\hline$\square$ & $x$ & 23 & & on & 5c:cf:7f:b2:e3:35 & 2017-11-13 05:09:12 \\
\hline$\square$ & $x$ & 24 & & on & c4:17:fe:88:e5:ad & $2017-11-13$ 05:09:12 \\
\hline$\square$ & $x$ & 25 & & on & dc:85:de:a7:11:fb & $2017-11-13$ 05:09:12 \\
\hline$\square$ & $x$ & 26 & & on & $5 c$ cf:7f:b2:e3:35 & $2017-11-13$ 05:09:22 \\
\hline$\square$ & $x$ & 27 & & on & c4:17:fe:88:e5:ad & $2017-11-13$ 05:09:22 \\
\hline$\square$ & $x$ & 28 & & on & dc:85:de:a7:11:fb & $2017-11-13$ 05:09:22 \\
\hline 0 & $x$ & 29 & 361 & on & 40:16:7e:ee:36:65 & $2017-11-13$ 05:11:37 \\
\hline
\end{tabular}

Figure 16. Status table

Status table consists of the status of the use of projector and the presence of lecturers classified in the identification based on wifi activation when connected with the access point

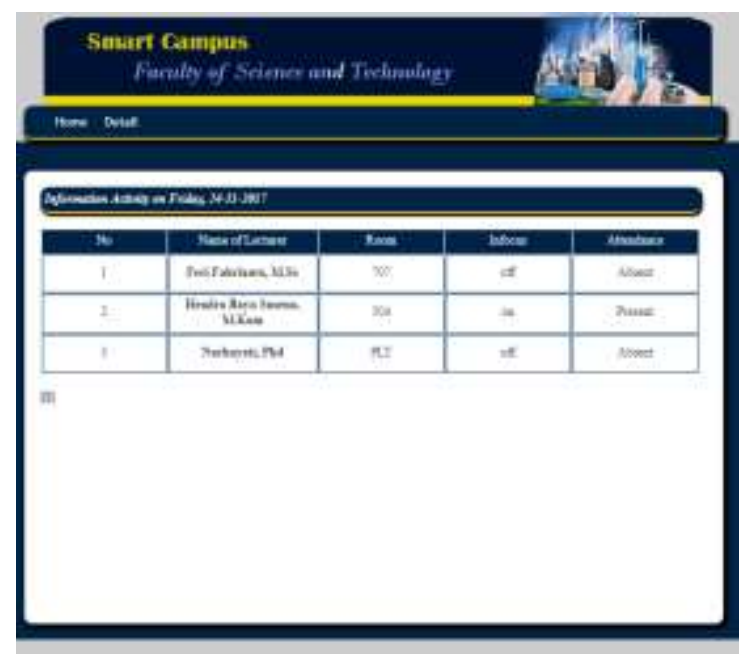

Figure 17. Main page

The screen at main page use to monitorize the condition of use infocus and presence of lecturer in the class room based on active time.

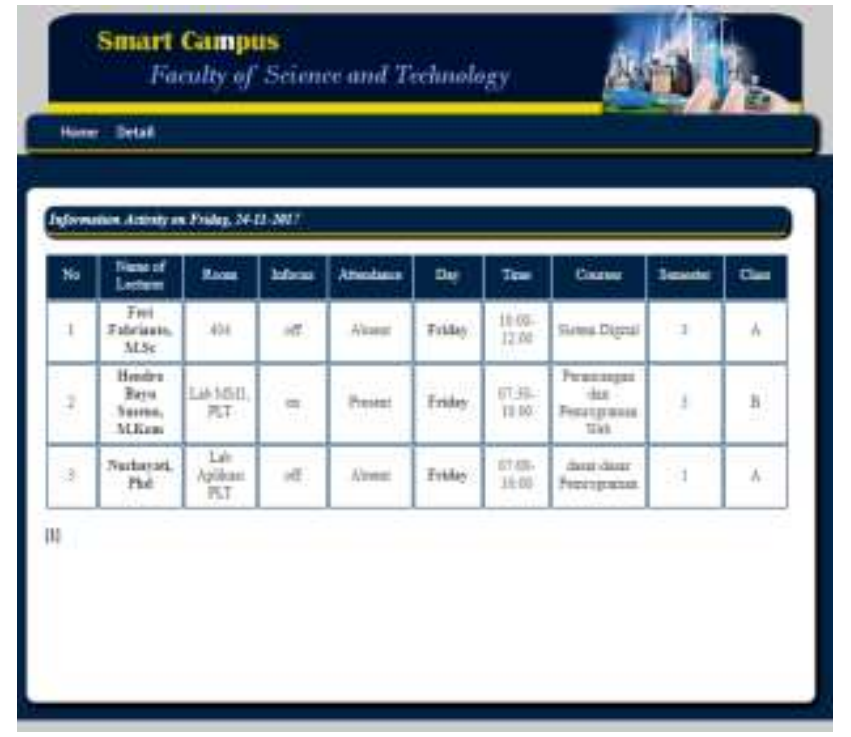

Figure 18. Detail page

Details view /mode tells information about schedule complete. Information system of activity presence of lecturer will be implemented by public network. topology from network implementation is used based on Local Area Network. 


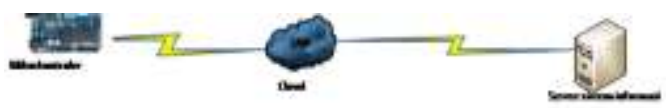

Figure 19. Network implementation

Figure 19 explained the implementation planning will be use a Local Area Network to communicate with a server.

\subsubsection{Black Box Testing}

At this phase will be conduct a testing for application functionality. This kind of testing is done to make sure that programm could be running well without any disturbance when it operating. For every test that is running there possibility erorr occured however by doing kind of testing erorr will be minimized.

Table 8. Black box testing

\begin{tabular}{|l|l|l|l|}
\hline No & Link & Output & Result \\
\hline 1 & $\begin{array}{l}\text { Send Data From } \\
\text { Microcontroller to } \\
\text { Server }\end{array}$ & Data is sent & Success \\
\hline 2 & $\begin{array}{l}\text { Showing a recent } \\
\text { condition of use } \\
\text { infocus and presence } \\
\text { of lecturer with } \\
\text { updated data in table } \\
\text { form table form }\end{array}$ & $\begin{array}{l}\text { New Information in } \\
\text { taccess }\end{array}$ & Sule \\
\hline 3 & $\begin{array}{l}\text { Showing schedule } \\
\text { complete data in table } \\
\text { form }\end{array}$ & Schedule complete in \\
table form & Success \\
\hline
\end{tabular}

IV. RESULT

\subsection{Monitoring System}

The author has developed a system for monitoring the use of current, temperatur and humidity. The author also used the technology so that the security system is becoming increasingly effective and efficient. In development, the authors use various technologies, such as Embedded systems, Database Technology and Web.

Nodemcu ESP 8266 and raspberry pi equipped with wireless uses as the brain of the system. This tool is in charge to process all the necessary activities in monitoring the attendance of the lecture. Nodemcu ESP 8266 requires a current sensor for monitoring against the electric current provided by LCD projector and the data captured by the sensor current is sent through a cloud service. In the manufacture of the system can be accessed online. Power source micro USB with 5V 2.0 Amps needed to provide power at ESP 8266 so it can be turned on and the monitoring of the well as required. Furthermore, the data generated by the Nodemcu ESP 8266 developed into the application monitoring system.

\subsection{Data Storage}

Data is stored into a MySQL-based database of current sensor and processed using the ESP 8266. It sends data to Raspberry Pi using Wifi Connection and the Raspberry pi will send tha data and store the data on database server

\section{REFERENCES}

[1] Qiang Liu, Yujun Ma, MusaedAlhusseinc, Limei Peng, Yin Zhang.Green data center with IoT sensing and cloud-assisted smart temperature controlling systembu IEEE access

http://ieeexplore.ieee.org/stamp/stamp.js $\mathrm{p}$ ?arnumber $=7317502$

[2] Xiang Sua, HaoZhangb, JukkaRiekkia, Ari Keranen, Jukka K. Nurminend, Libin Du. Connecting IoT Sensors to Knowledge-Based Systems by Transforming SenML to RDFby Procedia http://ubicomp.oulu.fi/files/pcs14.pdf

[3] Martin Fiedler and Stefan Meissner, IoT in Practice: Examples: IoT in Logistics and Health. By Royal institute of technology http://kth.divaportal.org/smash/get/diva2:621384/FUL LTEXT01.pdf

[4] ITU-T. ITU Internet Reports The Internet of Things by ITU https://www.itu.int/net/wsis/tunis/newsr oom/stats/The-Internet-of-Things2005.pdf

[5] Pressman, Roger S. 2010.software Engineering A Practitioner's Approach seventh Edition. New York: Mc Graw Hill higher Education.

[6] Holt, Huang. 2014. Embeded Operating Systems Practical Approach, Springer, London. UK. 
[7] Blum, 2012. Exploring Arduino Tools and Technique For Engineering Wizardy, Wiley, Indiana Polis. USA.

[8] Banzi, Massimo. 2011. Getting Started with Arduino. California: O'Reilly Media,inc

[9] Monk, Simon. 2013. Programming the Raspberry Pi Getting Started with Python. New York: The McGraw-Hill Companies.

[10] Current transformer YHDC SCT-013 https://openenergymonitor.org/emon/bui ldingblocks/ct-sensors-interface

[11] Temperature and humidity sensor DHT22:https://www.sparkfun.com/datas heets/Sensors/Temperature/DHT22.pdf

[12] Pfister, Cuno . 2015. Getting Started with the Internet of Things What Is. USA:O'Reilly Media,inc.

[13] Karen Rose, Scott Eldridge, Lyman Chapin. 2015. The Internet of Things: An Overview Understanding the Issues and Challenges of a More Connected World. The Internet Society (ISOC).
[14] Schwaber,Ken and Sutherland, Jeff. 2013. The Definitive Guide to Scrum: The Rules of the Game .The Scrum Guide ${ }^{\mathrm{TM}}$

[15] Kenneth S. Rubin. 2012.Essential Scrum A Practical Guide To The Most Popular Agile Process. Boston: Addison-Wesley.

[16] Goldstein, Ilan. 2013. Scrum Shortcuts without Cutting Corners Agile Tactics, Tools, \& Tips. Boston: Addison-Wesley - Pearson Education, Inc.

[17] Richardson, Matt. Wallace, Shawn. 2012. Getting Started with Raspberry Pi. USA: O'REILLY

[18] The Magpi. THE Official RASPBERRY PI PROJECTS BOOK by Magpi. London: Liz Upton

[19] Vermesan, Ovidium. Friess, Peter. Internet of Things Applications - From Research and Innovation to Market Deployment. Denmark: River Publisher 